\title{
ASSOCIATION OF CONGENITAL MALFORMATION OF THE HEART WITH BIRTH RANK AND MATERNAL AGE \\ BY \\ BRIAN MACMAHON*
}

From the Department of Social Medicine, University of Birmingham

\section{INTRODUCTION}

The literature contains few data on the association of congenital heart disease with birth rank and maternal age. This is not surprising in view of the difficulties of the investigation, which may be summarized as follows:

(1) The difficulty of assembling a series of cases of congenital heart disease which can be regarded as reasonably representative or complete. Many patients die in the neo-natal period, and the diagnosis is unreliable unless confirmed at autopsy. Alternatively, minor

* In receipt of a personal grant from the Medical Research Council. malformations of the heart are compatible with many years of life, and may be unrecognized even at death. The experience of any single clinician, pathologist, or hospital is of course quite unrepresentative.

(2) The difficulty of obtaining information about a satisfactory control group representative of the population of related births. Since information about siblings of affected children is inevitably incomplete, methods such as that of Greenwood and Yule (1914) cannot be applied and one must rely upon comparison with the population of births from which the affected are drawn.

In the present inquiry an attempt has been made to collect information about all cases of congenital

TABLE I

NUMBERS OF CASES OF CONGENITAL HEART DISEASE AND CONTROLS AT DIFFERENT BIRTH RANKS AND MATERNAL AGES

\begin{tabular}{|c|c|c|c|c|c|c|c|c|c|c|c|c|c|}
\hline \multirow{2}{*}{$\begin{array}{c}\text { Maternal } \\
\text { Age } \\
\text { (yrs) }\end{array}$} & \multicolumn{13}{|c|}{ BIRTH RANK } \\
\hline & 1 & 2 & 3 & 4 & 5 & 6 & 7 & 8 & 9 & 10 & 11 & $\begin{array}{l}12 \text { and } \\
\text { over }\end{array}$ & Total \\
\hline $\begin{array}{l}17 \\
18 \\
19 \\
20 \\
21 \\
22 \\
23 \\
24 \\
25 \\
26 \\
27 \\
28 \\
29 \\
30 \\
31 \\
32 \\
33 \\
34 \\
35 \\
36 \\
37 \\
38 \\
39 \\
40 \\
41 \\
42 \\
43 \\
44 \\
45 \\
46 \\
47 \\
48\end{array}$ & $\begin{array}{rr}7 & (2) \\
7 & (9) \\
8 & (22) \\
19(13) \\
21(34) \\
18(33) \\
10(54) \\
15(22) \\
15(32) \\
17(21) \\
6(26) \\
7(16) \\
9(26) \\
8(13) \\
2(11) \\
6(6) \\
4(9) \\
4(3) \\
3 & (5) \\
1 & (3) \\
2 & (5) \\
7 & (4) \\
- & - \\
2 & - \\
1 & (2) \\
- & - \\
- & - \\
- & - \\
- & - \\
- & - \\
- & - \\
- & -\end{array}$ & 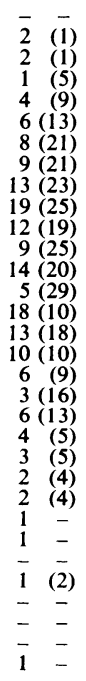 & $\begin{array}{rr}- & - \\
- & - \\
- & - \\
2 & - \\
2 & (1) \\
7 & (6) \\
2 & (7) \\
5 & (5) \\
6 & (7) \\
3 & (10) \\
9 & (6) \\
6 & (8) \\
3 & (10) \\
3 & (17) \\
6(12) \\
11 & (9) \\
6 & (9) \\
13(10) \\
4 & (7) \\
7 & (4) \\
6 & (3) \\
2 & (4) \\
2 & (1) \\
3 & (3) \\
2 & (1) \\
2 & (3) \\
1 & - \\
1 & (1) \\
1 & - \\
- & - \\
- & - \\
- & -\end{array}$ & $\begin{array}{l}-\overline{-} \\
-- \\
-- \\
-- \\
-- \\
-(1) \\
-(1) \\
1(1) \\
2(4) \\
-(5) \\
1(6) \\
5(9) \\
2(2) \\
4(4) \\
2(2) \\
5(8) \\
2(5) \\
2(3) \\
2(5) \\
3(6) \\
6(5) \\
5(6) \\
3(4) \\
-(4) \\
2(- \\
1(5) \\
1(1) \\
-(1) \\
-- \\
-- \\
-- \\
--\end{array}$ & $\begin{array}{l}-\overline{-} \\
-- \\
-- \\
-- \\
-- \\
-- \\
-- \\
-\overline{1} \\
1(1) \\
-(3) \\
1 \text { - } \\
1(2) \\
1(2) \\
1(4) \\
3(4) \\
2(1) \\
1(4) \\
-(3) \\
-(4) \\
2(2) \\
-(8) \\
1(1) \\
-(2) \\
4(1) \\
1(5) \\
-(1) \\
-(1) \\
-- \\
-- \\
-1- \\
1- \\
--\end{array}$ & 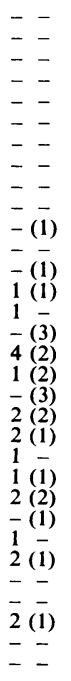 & 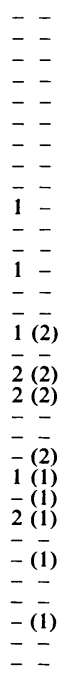 & $\begin{array}{l}-- \\
-- \\
-- \\
-- \\
-- \\
-- \\
-- \\
-- \\
-- \\
-- \\
-- \\
-- \\
-- \\
-\overline{-} \\
1- \\
-- \\
-- \\
-(1) \\
-(2) \\
-(1) \\
-- \\
-- \\
-(2) \\
1(1) \\
-(1) \\
1- \\
-- \\
-1- \\
-- \\
-- \\
--\end{array}$ & $\begin{array}{l}-- \\
-- \\
-- \\
-- \\
-- \\
-- \\
-- \\
-- \\
-- \\
-- \\
-- \\
-- \\
-- \\
-- \\
-- \\
-- \\
-- \\
-- \\
-- \\
-- \\
-- \\
-\overline{1} \\
-(1) \\
-\overline{1} \\
1(1) \\
-- \\
-(1) \\
-- \\
-(1) \\
-- \\
-- \\
--\end{array}$ & 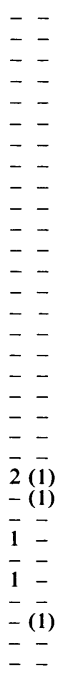 & 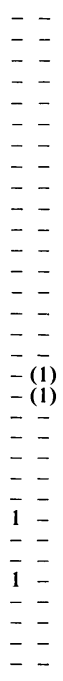 & 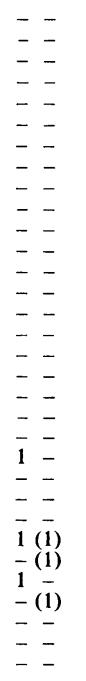 & $\begin{array}{r}-(2) \\
9(10) \\
10(23) \\
22(18) \\
27(44) \\
24(53) \\
20(83) \\
30(49) \\
37(67) \\
40(64) \\
29(58) \\
28(60) \\
30(61) \\
22(68) \\
33(39) \\
38(47) \\
27(39) \\
28(34) \\
14(45) \\
21(31) \\
20(27) \\
20(22) \\
11(17) \\
14(17) \\
11(12) \\
8(10) \\
4(6) \\
5(4) \\
2(2) \\
2(3) \\
10 \\
1 \quad-\end{array}$ \\
\hline Totals & $\begin{array}{c}192 \\
(371)\end{array}$ & $\begin{array}{c}175 \\
(308)\end{array}$ & $\begin{array}{c}108 \\
(144)\end{array}$ & $\begin{array}{c}49 \\
(88)\end{array}$ & $\begin{array}{c}20 \\
(49)\end{array}$ & $\begin{array}{c}20 \\
(22)\end{array}$ & $\begin{array}{c}10 \\
(13)\end{array}$ & $\begin{array}{c}4 \\
(8)\end{array}$ & $\begin{array}{c}1 \\
(4)\end{array}$ & $\begin{array}{c}4 \\
(3)\end{array}$ & $\begin{array}{c}2 \\
(2)\end{array}$ & $\begin{array}{c}3 \\
(3)\end{array}$ & $\begin{array}{c}588 \\
(1,015)\end{array}$ \\
\hline
\end{tabular}


heart disease born in Birmingham during a 10-year period, and these are compared with a control series representative of all births from the same years.

\section{MATERIAL}

The formation of the series, and the extent to which it can be regarded as complete, have been discussed fully in a communication dealing with the incidence of cardiac malformations (MacMahon, McKeown, and Record, 1952). It suffices to state here that the following sources of information were available:

(1) Records of all post-mortem examinations conducted in maternity, paediatric, and general hospitals in the city;

(2) Clinical records of all patients seen by consultant physicians or surgeons in the same hospitals;

(3) Records of all cases attending special schools or under the supervision of school medical officers in ordinary schools;

(4) Registers of stillbirths and infant deaths of the Local Authority.

Cases were accepted if born in the years 1940 to 1949 to mothers domiciled within the administrative boundary of Birmingham. These criteria were satisfied by 633 cases; after field inquiry, information about birth rank and maternal age was available for 588 (92.9 per cent.). The criteria of diagnosis varied considerably, but for a full statement on this question the reader is referred to the previous paper.

The control series was selected by taking every twohundredth name from the Local Authority's registers of live births and stillbirths notified during the same period. The series has previously been used in investigations of malformations of the central nervous system (Record and McKeown, 1949) and of infantile pyloric stenosis (McKeown, MacMahon, and Record, 1951), and is more fully described in these communications. For the present inquiry (1940-49), information about birth rank and maternal age was available for 1,015 ( 93.5 per cent.) of the 1,086 controls.

\section{FindingS}

Birth Rank AND Maternal Age.-The numbers of patients and controls at different birth ranks and maternal ages are given in Table I. Birth rank is calculated from the number of viable pregnancies, miscarriages (but not stillbirths) being excluded, and multiple pregnancies being counted once. Maternal age is the age of the mother at the birth of the propositus, and is calculated from the mother's date of birth. In a few cases maternal age is as given by the mother without reference to her date of birth.

TABLE II

DISTRIBUTIONS OF AFFECTED AND CONTROLS BY BIRTH RANK

\begin{tabular}{|c|c|c|c|c|c|}
\hline \multirow{2}{*}{$\begin{array}{l}\text { Birth } \\
\text { Rank }\end{array}$} & \multicolumn{2}{|c|}{ Affected } & \multicolumn{2}{|c|}{ Controls } & \multirow{2}{*}{$\begin{array}{l}\text { Difference } \\
(a)-(b)\end{array}$} \\
\hline & No. & $\begin{array}{l}\text { Per cent. } \\
(a)\end{array}$ & No. & $\begin{array}{l}\text { Per cent. } \\
\text { (b) }\end{array}$ & \\
\hline $\begin{array}{c}1 \\
2 \\
3 \\
4 \\
5 \text { and over }\end{array}$ & $\begin{array}{r}192 \\
175 \\
108 \\
49 \\
64\end{array}$ & $\begin{array}{r}32 \cdot 65 \\
29 \cdot 76 \\
18 \cdot 37 \\
8 \cdot 33 \\
10 \cdot 88\end{array}$ & $\begin{array}{r}371 \\
308 \\
144 \\
88 \\
104\end{array}$ & $\begin{array}{r}36 \cdot 55 \\
30 \cdot 34 \\
14 \cdot 19 \\
8 \cdot 67 \\
10 \cdot 25\end{array}$ & $\begin{array}{l}-3.90 \pm 2.47 \\
-0.58 \pm 2.37 \\
+4.18 \pm 1.89 * \\
-0.34 \pm 1.45 \\
+0.63 \pm 1.59\end{array}$ \\
\hline Totals & 588 & $100 \cdot 0$ & 1015 & $100 \cdot 0$ & - \\
\hline
\end{tabular}

The percentage distributions of the two series are given by birth rank (Table II) and by maternal age (Table III). Table II reveals no consistent association with birth rank, but in Table III there is an excess of controls in the age group 23-27, and, more definitely, a preponderance of affected individuals in the highest age group ( $38-48$ years). The 588 cases of known birth rank and maternal age include 35 mongols, which are mainly in the higher maternal age groups (fifteen are in the age group 38-48 years). When these are excluded (Table III, col. 3), differences between the two series are not significant, although the trends remain. In view of the large number of early deaths, it is unlikely that all mongols in the series were identified, and the inclusion of a few unrecognized cases may easily

TABLE III

DISTRIBUTIONS OF AFFECTED AND CONTROLS BY MATERNAL AGE

\begin{tabular}{|c|c|c|c|c|c|c|c|c|}
\hline \multirow{2}{*}{$\begin{array}{c}\text { Maternal } \\
\text { Age } \\
\text { (yrs) }\end{array}$} & \multicolumn{2}{|c|}{ Affected } & \multicolumn{2}{|c|}{$\begin{array}{l}\text { Affected with } \\
\text { Mongols excluded }\end{array}$} & \multicolumn{2}{|c|}{ Controls } & \multicolumn{2}{|c|}{ Difference } \\
\hline & No. & $\begin{array}{l}\text { Per cent. } \\
(a)\end{array}$ & No. & $\begin{array}{l}\text { Per cent. } \\
\text { (b) }\end{array}$ & No. & $\begin{array}{l}\text { Per cent. } \\
\text { (c) }\end{array}$ & $(a)-(c)$ & $(b)-(c)$ \\
\hline $\begin{array}{c}\text { Under } 23 \\
23-27 \\
28-32 \\
33-37 \\
38-48\end{array}$ & $\begin{array}{r}92 \\
156 \\
151 \\
110 \\
79\end{array}$ & $\begin{array}{l}15 \cdot 65 \\
26 \cdot 53 \\
25 \cdot 68 \\
18 \cdot 71 \\
13 \cdot 44\end{array}$ & $\begin{array}{r}90 \\
152 \\
147 \\
100 \\
63\end{array}$ & $\begin{array}{l}16 \cdot 30 \\
27 \cdot 54 \\
26 \cdot 63 \\
18 \cdot 12 \\
11 \cdot 41\end{array}$ & $\begin{array}{r}150 \\
321 \\
275 \\
176 \\
93\end{array}$ & $\begin{array}{r}14 \cdot 78 \\
31 \cdot 63 \\
27 \cdot 09 \\
17 \cdot 34 \\
9 \cdot 16\end{array}$ & $\begin{array}{l}+0.87 \pm 1.86 \\
+5 \cdot 10 \pm 2.37^{*} \\
-1.41 \pm 2.29 \\
+1.37 \pm 1.98 \\
+4.28 \pm 1.60^{*}\end{array}$ & $\begin{array}{l}+1.52 \pm 1.90 \\
-4.09 \pm 2.43 \\
-0.46 \pm 2.35 \\
+0.78 \pm 2.00 \\
+2.25 \pm 1.58\end{array}$ \\
\hline Total & 588 & $100 \cdot 0$ & 552 & $100 \cdot 0$ & 1,015 & $100 \cdot 0$ & - & - \\
\hline
\end{tabular}

* Difference exceeds twice its standard error.

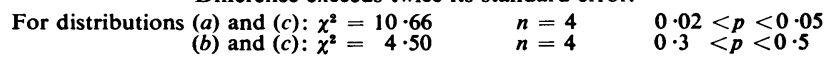


explain the slight residual preponderance of affected in the highest age group.

Distributions by birth rank when maternal age is constant, and by maternal age when birth rank is constant, have also been examined. The examination revealed no definite association with either variable when mongols were excluded.

For reasons discussed elsewhere (McKeown, MacMahon, and Record, 1951), consideration of maternal fertility in affected and controls is indispensable in the present method of examination of age and parity. The fertility of mothers of 100 cases of congenital heart disease selected at random from the series was compared with figures calculated for the controls in another inquiry. The results indicated that the distributions by birth rank and maternal age are unaffected by differences in maternal fertility.

The specific cardiac defect was identified in 239 of the 588 malformations of known birth rank and maternal age. (Diagnosis was accepted if confirmed post mortem, or, in the case of patent ductus arteriosus, at operation.) Distributions by birth rank and maternal age are given in Table IV. Three points may be noted:

(1) Distributions of the 239 confirmed cases by birth rank and maternal age do not differ from those recorded in Tables II and III for the complete series.

(2) The percentage of patients with patent ductus arteriosus who are firstborn is high $(52 \cdot 4)$, and differs significantly from that of controls $(36 \cdot 6$ : difference $15 \cdot 8 \pm 7 \cdot 6)$. Criteria for inclusion were:

(a) Confirmation at operation; there were nineteen cases (four males, fifteen females) of which ten (two males, eight females) were firstborn;

(b) Pathological enlargement of the ductus found post mortem in the early months of life.

The interpretation of the post-mortem findings in this group is difficult. One patient (a firstborn male) died at the age of 6 years and the lesion had been diagnosed by a consultant physician before death. Of the remainder (twelve males, ten females) the eldest was 7 months old and twelve were less than 1 week old at death. No case was included in this group unless the ductus was stated to be widely patent (in ten cases the ductus was said to be as wide as the aorta), but in view of the early age at death and the unusual sex ratio of the group, the diagnosis cannot be relied on. A further seventeen patients not included in Table IV (six males, eleven females) aged from 3 to 11 years had been seen by consultant physicians and were considered on clinical grounds to have a patent ductus arteriosus. Eight of them were firstborn. If patients seen by consultants are combined with those diagnosed at operation, the percentage of firstborn is $51 \cdot 4$, which differs from the controls by $14 \cdot 8 \pm 8 \cdot 1$. In spite of the doubt about diagnosis in the cases seen post mortem, these results suggest that birth rank may be of aetiological importance in patent ductus arteriosus.

(3) The proportion of patients in the group labelled "septal defects" who were born to mothers aged 38 years or over (23.9 per cent.) is high, and differs significantly from that in the control series $(9 \cdot 2$, difference $14 \cdot 7 \pm 3 \cdot 8)$. The association of mongolism with defects of the atrial and ventricular septa has been noted by Abbott (1927), and Silvy (1934, quoted by Brown, 1939), and is also exhibited in the present series. If the nine mongols of known birth rank and maternal age are excluded, the percentage over 38 years is reduced to 21.4. As mentioned above, ascertainment of mongols is almostly certainly incomplete, and this group of septal defects may be supposed to contain relatively more "missed" mongols than other groups. This must be borne in mind when the excess of cases of high maternal age in the group is considered.

OTHER FINDINGS. - The association of congenital heart disease with certain other variables was also examined, and the results, which are mainly negative, are briefly recorded. The series was distributed by

(a) month and quarter-year of birth,

(b) locality of domicile according to a classification of city wards described by Record and McKeown (1949).

The distributions did not differ significantly from the corresponding. distributions of all births in the city.

TABLE IV

NUMBERS OF MALFORMATIONS IN WHICH DIAGNOSIS WAS CONFIRMED AT OPERATION OR POST MORTEM AT DIFFERENT BIRTH RANKS AND MATERNAL AGES

\begin{tabular}{|c|c|c|c|c|c|c|c|c|c|c|c|c|c|c|}
\hline \multirow{2}{*}{\multicolumn{4}{|c|}{ Malformation }} & \multicolumn{5}{|c|}{ Birth Rank } & \multicolumn{6}{|c|}{ Maternal Age (yrs) } \\
\hline & & & & 1 & 2 & 3 & $\begin{array}{l}4 \text { and } \\
\text { over }\end{array}$ & Total & $\underset{23}{\text { Under }}$ & $23-27$ & $28-32$ & $33-37$ & $38-48$ & Total \\
\hline $\begin{array}{l}\text { Transposi } \\
\text { Persistent } \\
\text { Pulmonar } \\
\text { Coarctatio } \\
\text { Septal def } \\
\text { Patent duc } \\
\text { Other }\end{array}$ & $\begin{array}{l}\text { on } \\
\text { run } \\
\text { ste } \\
\text { n o } \\
\text { cts } \\
\text { tus } \\
\ldots\end{array}$ & $\begin{array}{l}\text { great ve } \\
\text { arterio } \\
\text { sis } \\
\text { orta } \\
\text { eriosus } \\
\text {. }\end{array}$ & $\begin{array}{l}\text { essels } \\
\text { osus } \\
\ldots \\
\ldots \\
\ldots \\
\ldots \\
\ldots\end{array}$ & $\begin{array}{r}10 \\
9 \\
6 \\
9 \\
20 \\
22 \\
12\end{array}$ & $\begin{array}{r}13 \\
4 \\
2 \\
8 \\
18 \\
8 \\
7\end{array}$ & $\begin{array}{r}7 \\
2 \\
7 \\
4 \\
12 \\
5 \\
7\end{array}$ & $\begin{array}{r}3 \\
1 \\
6 \\
4 \\
17 \\
7 \\
9\end{array}$ & $\begin{array}{l}33 \\
16 \\
21 \\
25 \\
67 \\
42 \\
35\end{array}$ & $\begin{array}{r}5 \\
6 \\
6 \\
5 \\
7 \\
10 \\
6\end{array}$ & $\begin{array}{r}11 \\
5 \\
5 \\
6 \\
17 \\
14 \\
10\end{array}$ & $\begin{array}{r}10 \\
4 \\
3 \\
5 \\
18 \\
3 \\
8\end{array}$ & $\begin{array}{l}6 \\
0 \\
4 \\
4 \\
9 \\
8 \\
9\end{array}$ & $\begin{array}{r}1 \\
1 \\
3 \\
5 \\
16 \\
7 \\
2\end{array}$ & $\begin{array}{l}33 \\
16 \\
21 \\
25 \\
67 \\
42 \\
35\end{array}$ \\
\hline $\begin{array}{l}\text { Totals } \\
\text { Per cent. }\end{array}$ & $\begin{array}{l}\cdots \\
\cdots\end{array}$ & $\begin{array}{l}\cdots \\
\cdots\end{array}$ & $\begin{array}{l}\cdots \\
\ldots\end{array}$ & $\begin{array}{c}88 \\
(36 \cdot 8)\end{array}$ & $\begin{array}{c}60 \\
(25 \cdot 1)\end{array}$ & $\begin{array}{c}44 \\
(18 \cdot 4)\end{array}$ & $\begin{array}{c}47 \\
(19 \cdot 7)\end{array}$ & $\begin{array}{c}239 \\
(100 \cdot 0)\end{array}$ & $\begin{array}{c}45 \\
(18 \cdot 8)\end{array}$ & $\begin{array}{c}68 \\
(28 \cdot 5)\end{array}$ & $\begin{array}{c}51 \\
(21 \cdot 3)\end{array}$ & $\begin{array}{c}40 \\
(16 \cdot 7)\end{array}$ & $\begin{array}{c}35 \\
(14 \cdot 6)\end{array}$ & $\begin{array}{c}239 \\
(100 \cdot 0)\end{array}$ \\
\hline \multicolumn{4}{|c|}{1,015 controls (per cent.) } & $(36 \cdot 6)$ & $(30 \cdot 3)$ & $(14 \cdot 2)$ & $(18 \cdot 9)$ & $(100 \cdot 0)$ & $(14 \cdot 8)$ & $(31 \cdot 6)$ & $(27 \cdot 1)$ & $(17 \cdot 3)$ & $(9 \cdot 2)$ & $(100 \cdot 0)$ \\
\hline
\end{tabular}


In the course of the inquiry, 477 mothers were interviewed and details of maternal health during pregnancy were recorded. Bacterial and viral diseases were the subject of a specific question. Results of a similar inquiry on 742 controls were available for comparison. There was no evidence of increase in the incidence of any of the common causes of maternal ill health during pregnancy, or of association between any particular cause of ill health and a specific heart lesion. Only one mother (of a patient with unconfirmed patent ductus arteriosus and congenital deafness) gave a definite history of rubella. Another mother (the patient also had patent ductus arteriosus) had had an undiagnosed rash lasting 1 week. Both these illnesses occurred during the first trimester of pregnancy.

\section{Discussion}

There have been two previous examinations of the association of congenital heart disease with birth rank and maternal age. Still (1927) reported that of 280 cases of congenital heart disease, 96 (34. 3 per cent.) were firstborn, as compared with 18.5 per cent. in a control series. Lamy and Schweisguth (1950) concluded that neither birth rank nor maternal age had any effect in a series of 304 cases, but gave no evidence in support of this statement. The findings in the present investigation suggest that cardiac malformations as a group are not associated with birth rank or maternal age, except in so far as they are associated with mongolism. Still's results are probably due to the method of selection of the control group, which was almost certainly deficient in the early birth ranks.

Although useful as a preliminary, consideration of cardiac malformations as a group is far from ideal, and in Table IV specific malformations are examined separately. Of course numbers are small; nevertheless an association with birth rank is evident in the case of patent ductus arteriosus. This suggests that the environment influences the incidence of the defect, presumably at the time of birth when the ductus normally closes. In this connection the observations of Kennedy and Clark (1942) on the stimulation of closure by inhalation or intravenous injection of oxygen, and of Barclay (1946) on failure of the ductus to close when the general condition of the subject is poor, are of interest.

Association has also been noted between incidence of septal defects and high maternal age. It seems likely that this is the result of the association of septal defects with mongolism, but on the present data it is not possible to provide confirmation.
Although it is now established that congenital heart disease may result from rubella contracted by the mother during the early months of pregnancy, the number of such cases seems to be extremely small, even when allowance is made for the inaccuracies of retrospective investigations. A history of rubella was elicited in five out of 434 cases by Dogramaci and Green (1947), in four out of 250 by Campbell (1949), in two out of 225 by Lamy and Schweisguth (1950), and in one, possibly two, out of 477 in the present inquiry. In reported cases of congenital heart disease following rubella, isolated cardiac defects are rare; in the great majority they are associated with cataract or congenital deafness. The fact that the great majority of patients with congenital heart disease do not exhibit these other malformations also suggests that maternal rubella accounts for no more than a small percentage of cardiac defects.

\section{Summary}

(1) An attempt has been made to collect all known cases of congenital heart disease born to Birmingham mothers in the years $1940-49$, by examination of:

(a) post-mortem and clinical records of all Birmingham hospitals;

(b) reports of school medical officers,

(c) registers of infant deaths.

For comparison, a control series consisting of every two-hundredth birth in the city over the same period is available. Data on birth rank and maternal age are recorded for 588 (92.9 per cent.) of 633 affected, and for 1,015 (93.5 per cent.) of 1,086 controls.

(2) Distributions of affected and controls by birth rank and maternal age are compared. In the highest maternal age group examined (38-48) the proportion of affected is significantly higher than that of controls, but the difference is considerably reduced and is not significant when known mongols are excluded from the affected. There is no definite association with birth rank.

(3) Diagnosis was confirmed at post mortem or operation in 239 of the 588 patients (Table IV). Numbers of cases of any specific cardiac defect are small, and the only conspicuous associations with birth rank or maternal age are exhibited by:

(a) patent ductus arteriosus, which is more common in first births than in later births;

(b) septal defects, which are unduly common in children of older mothers.

(4) There is no evidence that the incidence of congenital heart disease is related to season of birth, 
locality of domicile, or maternal ill health during pregnancy.

For facilities in the collection of case records, I am indebted to the staff of the Birmingham Children's Hospital, in particular Dr. Clifford Parsons who made available the records of the congenital heart clinic; to the staffs of all other Birmingham hospitals, in particular Selly Oak and Dudley Road; to Dr. H. S. Baar, Dr. W. Whitelaw, and other hospital pathologists for access to post-mortem material: to Dr. H. M. Cohen, Dr. M. E. Lemin, and their assistant school medical officers for organizing and executing an inquiry into the numbers of cases of congenital heart disease among school children; to Dr. Jean Mackintosh and the staff of the Maternity and Child Welfare Department for free access to departmental records.
I am also greatly indebted to Miss $M$. S. Gradwell, who conducted the field inquiry in the homes of patients and assisted in the collection of case records, and to Dr. Audrey Heywood, who assisted in the analysis of the data.

\section{REFERENCES}

Abbott, M. E. (1927). "Nelson's Loose-leaf Living Medicine", vol. 4, p. 207. Nelson, New York.

Barclay, A. E. (1946). Proc. roy. Soc. Med., 39, 112.

Brown, J W (1939). "Congenital Heart Disease”, Bale, London.

Campbeli, M. (1949). Q Quart. J. Med., 18, 379.

Dogramaci, I., and Green, H. (1947). J. Pediat., 30295.

Greenwood, M., and Yule, G. U. (1914). J. roy. statist. Soc., 77, 179 Kennedy, J. A., and Clark, S. L. (1942). Amer. J. Physiol., 136, 140 Lamy, M., and Schweisguth, O. (1950). Ann. Paediat, Basel, 174,65 .

McKeown, T., MacMahon, B. and Record, R. G. (1951). Ann. Eugen., Camb., 16, 249.

MacMahon, B., McKeown, T., and Record, R. G. (1952). In the press. Record, R. G., and McKeown, T. (1949). British Journal of Social Medicine, 3, 183.

Silvy, M. (1934). Quoted bv Brown (1939).

Still, G. F. (1927). Lancet, 2, 795. 